\title{
Application of learning model with virtual lab and motivation in learning chemistry
}

\author{
Gulmah Sugiharti ${ }^{1 *}$, Eva Rofinta Limbong ${ }^{1}$ \\ ${ }^{1}$ Department of Chemistry, Faculty of Mathematics and Natural Science, Universitas Negeri Medan, Medan-Indonesia
}

\section{Abstract:}

This study aims to determine whether there is interaction between learning models and motivation to student learning outcomes. Samples were taken by purposive as much as 2 classes, experimental class 1 was treated with Problem Based Learning model using Virtual Lab and experiment II class was treated with PBL model using Real Lab on acid base titration material. Student learning outcomes data obtained using the test results of learning, while the data for motivation to learn through questionnaire motivation to learn. The data analysis technique uses twoway variance analysis and Fcount test. The results showed: 1) Hypothesis test obtained Fcount (A) and (B) equal to 18,55l> Ftabel $(0,05)(1,48)=4,04$ hence there is interaction between learning model using virtul lab and motivation learn to result learn chemistry of students. 2) Highly motivated students, taught by PBL model using Virtual Lab gives the highest average learning result $(75,536$ 10,10), whereas taught by PBL model using real lab give average $(75,2,43)$. 3) Students with low learning motivation, taught by PBL model using Virtual Lab give the average of learning result (71,59 10,74), whereas taught by PBL model using Real Lab give average $(72,32$ 10,94). Thus it is concluded that there is an interaction between learning model and learning motivation toward chemistry learning result, and students who have high learning motivation are taught by PBL model using virtual lab give higher mean, whereas students who have low learning motivation are taught by PBL model using virtual lab provides a low average learning outcome.

Keywords:

learning outcomes, motivation, PBL model, virtual lab, real lab

\section{Introduction}

Chemistry subjects are contained in scientific theory and students must practice to ful fill the indicator of material success. The acid-base titration syllabus requires students to be able to design, perform, and conclude and present the results of acid-base titration experiments. Beach and Stone stated that by practicum in the laboratory is an efficient way of learning chemistry. Then Demirci says "Laboratory Methods" is one of the learning methods which allows students to prove basic scientific facts in the laboratory space (Tatli \& Alipasa, 2010).

With virtual labs students can see and interact with their own experiments. The virtual lab allows students to conduct chemical experiments as if facing real laboratory equipment. So the expected goal of chemistry learning as a scientific process will be achieved at a cheaper cost, and a shorter time (Sanova, 2013). The application of virtual laboratory applications to chemistry learning was found to be more effective because of improved student performance. Achievement levels (high, medium \& low) do not have significant differences in students

\footnotetext{
* Corresponding author.

gulmahsugiharti@unimed.ac.id

doi: https://doi.org/10.24114/jpkim.v10i1.9676
}

taught using virtual learning in collaborative and individual settings. While Sugiharti \& Hasibuan (2017) finds the effect of virtual lab and real laboratory on students' learning achievement, and the use of virtual laboratories gets an average value greater than real laboratory usage. Virtual Laboratories quickly replaced the Real Laboratory as a practicum medium for teaching and learning science in the school environment. Van Lejeune and Mint describe three main reasons for using Virtual labs as a practicum medium. First, material for real labor is very expensive; Second, the use of chemicals in the classroom has the potential to cause lawsuits if chemicals are not handled either by teachers or students; Third, virtual labs can provide a quality experience for students, and more secure.

A virtual laboratory is a program that contains laboratory tools that work like a real tool. The advantages of virtual labs are that they can make learning more time efficient. It also can save costs, given the more expensive chemicals (Fitriyana, 2013). The results of Tuysuz (2010), concluded that virtual laboratories can effectively improve student learning outcomes and provide a positive impact on the formation of student characters. The use of virtual lab and real lab in learning will be more effective if adapted to the learning model, one of the learning model that can be used is PBL. 
Problem-based learning challenges students to work together in groups to find solutions to problems and to develop self-study skills. The instruction is more student-centered. Learning will become active. This problem-based learning enables students to improve critical thinking skills, analyze, and solve problems (Akcay, 2009). PBL also has a positive impact in improving students' learning motivation, self study and soft skill. This is because, PBL uses learning problems as a catalyst to encourage students to think critically. Group learning activities and leadership roles help to develop communication and collaboration of student abilities (Surif et al., 2013).

This study aims to determine whether there is a significant interaction between the learning model by using media and learning motivation to the students 'learning outcomes on acid-base titration material, is there a significant influence on the learning model by using the media to the students' learning outcomes on acid-base titration materials and whether there is a significant influence on learning motivation on student learning outcomes on acid-base titration material.

\section{Materials and Methods}

This research is an expriment research in SMA N 1 Galang academic year 2016/2017. The research design used is $2 \times 2$ factorial design. There are two factors studied namely learning model model using laboratory (A) and learning motivation factor (B). Factor $\mathrm{A}$ there are two levels of learning model PBL using real lab and PBL learning model using virtual lab. For factor B there are two levels of learning motivation is high and low. In detail the design of this study is presented in Table 1.

Research instrument in the form of learning result and motivation questionnaire developed based on learning motivation indicators in the theoretical framework. Analysis of the data using the average score, where students who score above the average are grouped as students who have high learning motivation and students who scored below the average grouped as students who have low learning motivation. The research design is complete in Fig 1.

Table 1

$2 \times 2$ Factorial research design

\begin{tabular}{ccc}
\hline & \multicolumn{2}{c}{ Learning Model $(A)$} \\
\cline { 2 - 3 } Motivation to & PBL with Virtual & PBL with Riil \\
Learn (B) & Media $\left.A_{1}\right)$ & Media $\left(A_{2}\right)$ \\
\hline High $\left(B_{1}\right)$ & $A_{1} B_{1}$ & $A_{2} B_{1}$ \\
Low $\left(B_{2}\right)$ & $A_{1} B_{2}$ & $A_{2} B_{2}$ \\
\hline
\end{tabular}

Note:

$A B$ is a combination of Treatment of PBL Model with Virtual media and high learning motivation; $A B$ is a combination of $\mathrm{PBL}$ model treatment with Virtual media and low learning motivation $A B$ is a combination of PBL model treatment with Real media and high learning motivation; $A B$ is a combination of PBL model treatment with Real media and low learning motivation.

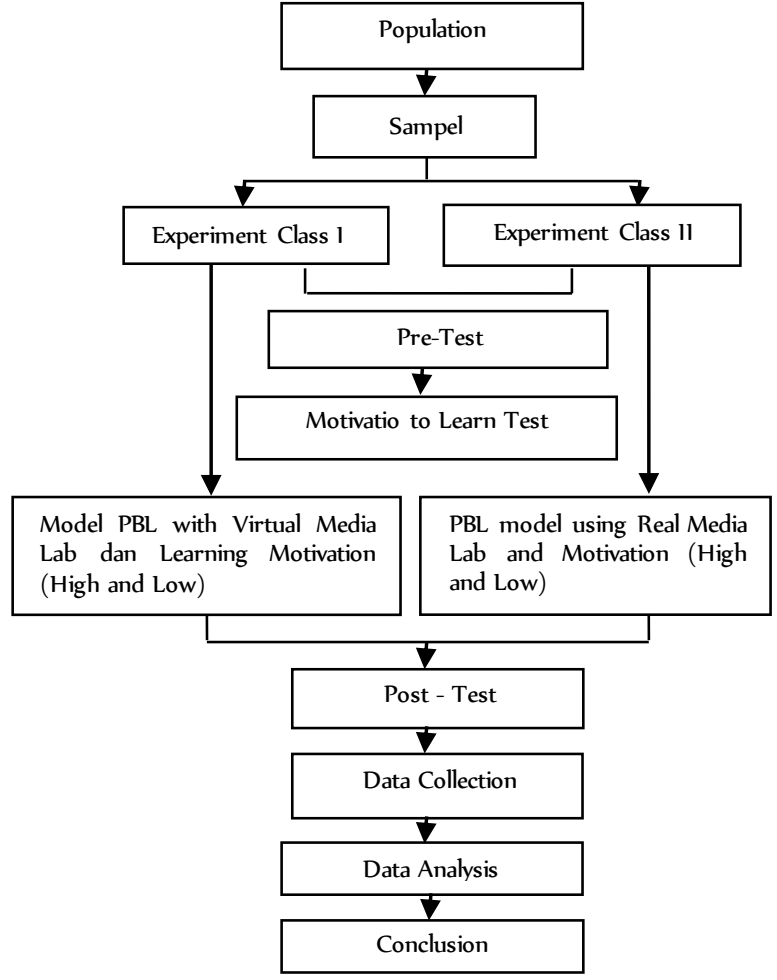

Fig 1. Form of research design

\section{Results}

The result of questionnaire motivation to learn the qualified students as much as 40 items. Student motivation data are grouped into two categories: high student learning motivation $\geq$ average value of student learning motivation. Low motivation category of learning for students who have a value of $\leq$ the average value of student learning motivation. Overall high and low learning motivation data are shown in Table 2.

Chemical learning result data in this research is obtained from posttest value. From the data processing obtained that for students who are taught with PBL learning model with a virtual lab with high motivation obtained average learning outcomes (75,54 10.10), for classes taught by PBL learning model with virtual lab media with low motivation obtained average results learning $(71,59,10,74)$, for class which taught by PBL learning model with real lab media with high motivation obtained by average learning result $(75,2,43)$, for class taught by PBL learning model with real lab media with low motivation obtained the average of learning result $(72,3210,94)$. The average details of the chemical learning outcomes obtained by the students for each treatment combination are presented in Table 3.

Hypothesis testing is done by Analysis of Variance (ANAVA) test at $\alpha=0,05$ with criterion if Fhitung $<$ Ftabel then Ha accepted. Based on the calculation of hypothesis test data of students' chemistry learning, it is concluded that there is an interaction between 
Learning Motivation (B) and Learning Model Using Media (A) on the chemistry result of high school students. Anava list of high school student grades given a combination of learning model treatment using laboratory media and learning motivation is presented in Table 4.

Table 2

Data distribution of learning motivation high and low

\begin{tabular}{cccc}
\hline \multirow{2}{*}{$\begin{array}{c}\text { Learning } \\
\text { Motivation }\end{array}$} & $\begin{array}{c}\text { Sum of } \\
\text { Data }\end{array}$ & $\begin{array}{c}\text { Experiment } \\
\text { Class 1 }\end{array}$ & $\begin{array}{c}\text { Experiment } \\
\text { Class 2 }\end{array}$ \\
\cline { 3 - 4 } & & \multicolumn{2}{c}{ Frequency } \\
\hline High & 26 & 14 & 12 \\
Low & 25 & 11 & 14 \\
Total & 51 & 25 & 26 \\
\hline
\end{tabular}

Table 3

Average learning outcomes of chemistry are given a combination of learning model treatment using laboratory and learning motivation

\begin{tabular}{ccc}
\hline \multirow{2}{*}{$\begin{array}{c}\text { Learning } \\
\text { Motivation }\end{array}$} & \multicolumn{2}{l}{ Learning Models Using Laboratory $(A)$} \\
\cline { 2 - 3 }$(B)$ & PBL Model Using & PBL Model Using \\
High $\left(B_{1}\right)$ & $(75,54 \pm 10,10)$ & RealMedia Lab $\left(A_{2}\right)$ \\
Low $\left(B_{2}\right)$ & $(71,59 \pm 10,74)$ & $(75,2 \pm 9,43)$ \\
\hline
\end{tabular}

\section{Discussion}

Interaction betwenn learning models with virtual lab an motivation to learning outcomes

Hypothesis test obtained Fcount (A) and (B) equal to $18,551>$ Ftabel $(0,05)(1,48)=4,04$ hence there is significant interaction between learning model using virtul lab and motivation learn to result of chemistry learning students on acid-base titration material.

Table 4

The chemical values of students who were given a combination of the treatment of learning models using the laboratory and learning motivation

\begin{tabular}{ccrrrr}
\hline $\begin{array}{c}\text { Variance } \\
\text { Source }\end{array}$ & Db & JK & KT & $\mathbf{F}_{\text {count }}$ & $\begin{array}{c}\mathbf{F} \\
(\mathbf{0 , 0 5}, \\
\mathbf{d b})\end{array}$ \\
\hline Treatment & 3 & 3366,361 & 3366,361 & - & - \\
Factor A & 1 & 92,890 & 92,890 & 0,619 & 4,04 \\
Factor B & 1 & 489,236 & 489,236 & 3,260 & 4,04 \\
Interaction & 1 & 2784,235 & 2784,235 & 18,551 & 4,04 \\
AB & 48 & 7204,019 & 150,084 & & \\
Error & 54 & 13936,74 & 6882,806 & - & - \\
Total & & & & & \\
\hline
\end{tabular}

In this study, it was found that if the factor of learning model using laboratory (factor A) and learning motivation (factor B) were combined, it was found that the interaction between the two factors significantly affected the students' chemistry learning result. The form of interaction factor of learning model by using laboratory (factor A) and learning motivation (factor B) on student's chemistry learning result can be seen in Fig 2 .
Based on interaction form Fig 2, can be concluded that teaching using PBL model with virtual lab and high motivation give highest student learning result. While teaching using PBL model with real lab and high motivation gives students lower learning outcomes, with averages and 75,536 10,10 and 75,2 9.44. Furthermore, teaching using PBL model with virtual media and low motivation resulted in low student chemistry result with chemistry learning result which taught using PBL model with real media and low motivation to give low student chemistry result, with 71,59 10, 74 and 72.310 .94 . The average learning outcomes of chemistry students who have high learning motivation obtained higher learning outcomes in the experimental class 1 given the teaching with the PBL model using virtual lab from the experimental class 2 given teaching with $\mathrm{PBL}$ model using real lab. This is because the PBL model makes students more active in conducting a series of scientific assisted with the use of laboratory media. This is in accordance with the opinion of lsrafiddin et al. (2016) stated that the PBL model improves students' scientific attitude better. Agraw et al. (2016) says that teaching with $\mathrm{PBL}$ is more effective. The results of Setyorini et al. (2011) indicates that the PBL model invites students to be directly involved in the learning process. While Aprilia (2015) found that the use of PBL models with virtual labs is better than PBL learning with real laboratories. The study of Marlinda et al. (2016) also found that there is increased motivation and learning activities of learners on learning with virtual lab and with experimental methods. Motivation and learning activities of learners in Virtual Lab class is higher than experimental class.

\section{Effect of motivation to learning outcomes}

Highly motivated students, taught by PBL model using Virtual Lab gives the highest average learning result $(75,53610.10)$, whereas taught by PBL model using real lab give average $(75,2,43)$. 3) Students with low learning motivation, taught by PBL model using Virtual Lab give the average of learning result (71,59 10,74), while taught by PBL model using Real Lab give average $(72,3210,94)$. Thus it is concluded that there is an interaction between learning model and learning motivation toward chemistry learning result, and students who have high learning motivation are taught by PBL model using virtual lab give higher mean, whereas students who have low learning motivation are taught by PBL model using virtual lab provides a low average learning outcome.

\section{Effect of virtual lab to learning outcomes}

Fcount $(\mathrm{AB})>\mathrm{F}(0.05)(1: 24)$ where $(15,350>$ $4,26)$, then it means there is a significant influence of the learning model by using the laboratory on the student's chemical learning on acid-base titration material. Learning model used in this research is PBL learning model using virtual laboratory and real laboratory. The results of research Fahmida et al. 
(2016) found that learning by using PBL model can improve students 'activity in asking, students' curiosity about the material, and during the learning process the students become more focused. Students get a more meaningful learning experience so that students' understanding is also better which causes student learning outcomes to increase. Furthermore, Fadliana et al. (2013) found that there is an influence on the use of PBL learning on student achievement. Learning with the PBL model makes students more active in learning, PBL is not only limited to problem solving but also a constructive learning that raises the problems in everyday life. Similarly, Sugiharti's research findings, et al. (2017) that learning by using PBL model and Dl model is considered to be able to develop a learning model capable of fostering students toward scientific thinking, only by using a more centralized DI model emphasis on learning materials, while the PBL model will provide flexibility for students to review other materials related to the business of students to improve their ability to handle the problems that occur in everyday life in the community. 3. Fcount $(A B)>F(0.05)(1: 24)$ where $(8,127>4,26)$, meaning that there is a significant influence on the learning model by using the laboratory and low learning motivation on the students' chemistry learning on the titration material acid base. From the data of student learning result concluded that student's learning motivation have influence to student's chemistry learning result on acid-base material. So it is concluded that students who have high motivation to give a higher average of chemistry learning outcomes compared with students who have low learning motivation.

The material of acid-base titration is a matter of a count. So that required motivation to learn students to be able to understand the material and able to solve the problem of acid-base titration and its concepts. Oktavia et al. (2016) states that one of the factors of students is difficult in doing calculations and in understanding the material is the absence of low learning motivation or student motivation.

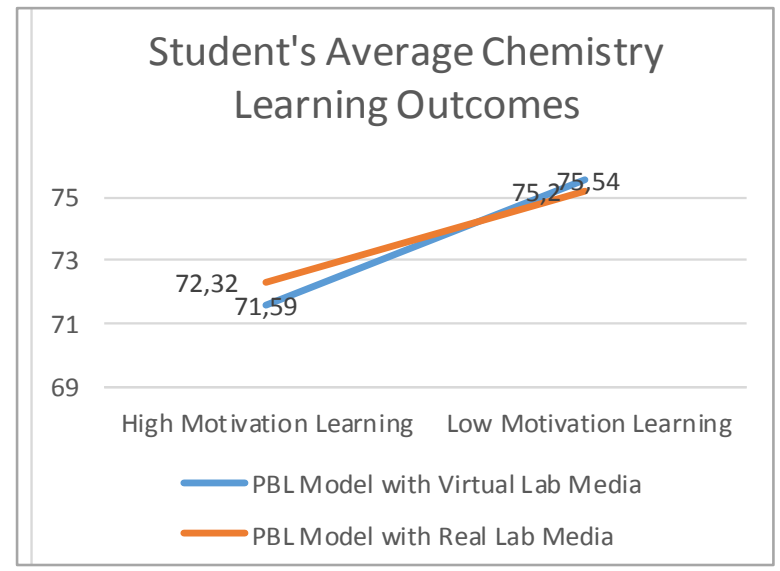

Fig 2. Form of interaction factor learning model using laboratory (Factor A) and learning motivation (Factor B) to student's chemistry learning result.

\section{Conclusion}

Based on the results of research that has been done then it can be concluded, (1) There is a significant interaction between the learning model by using media and learning motivation on the students' chemistry learning on acid base titration material; (2) There is a significant influence on the learning model by using media to the students' chemistry learning on acid-base titration material; (3) There is a significant influence on learning motivation toward student's chemical learning on acid-base titration material.

\section{Acknowledgments}

To the rector of State University of Medan that has granted permission field research and to $\mathrm{Mr}$. Principal and teacher of SMAN 1 Galang are on the premises and the class to study.

\section{References}

Argaw, A.S., Haile, B.B., Ayalew, B.T., \& Kuma, S.G. (2016). The Effect of Problrm Based Learning (PBL) Instruction on Students' Motivation and Problem Solving Skills of Physics. EURASIA Journal of Mathematics Science and Technology Education. 13, 857-871.

Aprilia, S. (2015). Pembelajaran Kimia Berbasis Masalah (Problem Based Learning) Dengan Menggunakan Laboratorium Real dan Virtual Ditinjau Dari Gaya Belajar Siswa Di SMA Negeri 1 Boja Tahun Pelajaran 2010/2011. Jurnal Profesi Pendidik. 2, 40-49.

Akcay, B. (2009). Problem-Based Learning in Science Education. Journal Turkish Science Education. 6, 26-36.

Fadliana, H.N., Redjeki, T., \& Nurhayati, N.D. (2013). Studi Komparasi Penggunaan Metode PBL (Problem Based Learning) Dilengkapi Dengan Macromedia Flash Dan LKS (Lembar Kerja Siswa) Terhadap Prestasi Belaja Ditinjau Dari Motivasi Belajar Siswa Materi Asam, Basa Dan Garam Kelas VII SMP Negeri 1 Jaten Karanganyar Tahun Pelajaran 2012/2013. Jurnal Pendidikan Kimia. 2, 158-165.

Mulyani, B., \& Sri Retno R.D.A. (2013). Pengaruh Pembelajaran Kimia Dengan Metode Student Team Achievement Division (STAD) Yang Dilengkapi Eksperimen Laboratorium Riil Dan Virtual Terhadap Prestasi Belajar Pada Materi Pokok Koloid Ditinjau Dari Kemampuan Memori SiswaKelas XI IA SMA N 8 SurakartaTahun Ajaran 2011/2012. Jurnal Pendidikan Kimia. 2, 130-138.

Israfiddin., Gani, A., \& Saminan., (2016), Penerapan Model Problem Based Learning Untuk Meningkatkan Sikap Ilmiah Dan Hasil Belajar Peserta Didik Pada Materi Gerak Di SMP Negeri 2 Delima. Jurnal Pendidikan Sains Indonesia. 2, 3644.

Marlinda., Halim, A., \& Aulana, 1. (2016). Perbandingan Penggunaan Media Virtual Lab 
Simulasi PhET (Physics Education Tekhnology) Dengan Metode Eksperimen Terhadap Motivasi Dan Ativitas Belajar Peserta Didik Pada Materi Kelarutan Dan Hasil Kali Kelarutan. Jurnal Pendidikan Sains Indonesia. 4, 69-82.

Octaviany, M., Mulyani, S., \& Susanti, E.V.H. (2014). Pengaruh Model Pembelajaran Problem Based Learning Dan Inquiry Terhadap Prestasi Belajar Siswa Ditinjau Dari Kreativitas Verbal Pada Materi Hukum Dasar Kimia Kelas X SMAN 1 Boyolali Tahun Pelajaran 2013/2014. Jurnal Pendidikan Kimia. 3, 162-169.

Sanova, A. (2013). Implementasi Metode Problem Based Learning (PBL) Berbantuan Diagram Vee Dalam Pembelajaran Kimia Berbasis Virtual Lab Untuk Meningkatkan Pemahaman Konsep Belajar. Jurnal Pendidikan Kimia. 5, 31-38.

Setyorini, U., Sukiswo, S.E., \& Subali, B. (2011). Penerapan Model Problem Based Learning Untuk. Meningkatkan Kemampuan Siswa SMP. Jurnal Pendidikan Fisika Indonesia. 7, 52-56.

Sugiharti, G., \& Hasibuan, S.K. (2017). The Effect of Inquiry Learning Method by Using Laboratory and Logical Thinking on Learning Outcome in Chemical Reaction Rate. Jurnal Pendidikan Kimia. 9, 229-235.
Sugiharti, G., Hamid, K.A., Mukhtar. (2017). The Effect of Learning Model and Mathematical Ability into Student's Learning Outcomes in Evaluation Course of Chemistry Education State University of Medan. Advances in Social Science, Education and Humanities Research. 104, 295299.

Surif, J., lbrahimb, N.H., \& Mokhtarc, M. (2013). Implementation of problem based learning in higher education institutions and its impact on students' learning. PBL Across Cultures. 66.

Tatli, Z., \& Alipasa, A. (2010). Virtual Laboratory Applications In Chemistry, Education. Procedia Social and Behavioral Sciences. 9, 938-942.

Yoon, H., Woo, A. J., Treagust, D.F., \& Chandrasegaran, A.L. (2014). The Efficacy of Problem-based Learning in an Analytical Laboratory Course for Pre-service Chemistry Teachers. International Journal of Science Education. 36, 79-102.

Tuysuz, C. (2010). The Effect of the Virtual Laboratory on Students' Achievement and Attitude in Chemistry. Journal of Educational Sciences. 2, 37-53. 